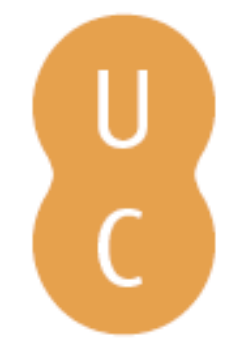

\title{
pommalina
}

\section{Reliability Analysis on Crucial Subsystems of a Wind Turbine through FTA Approach}

Autor(es): $\quad$ Katsavounis, S.; Patsianis, N.; Konstantinidis, E.I.; Botsaris, P.N.

Imprensa da Universidade de Coimbra; Faculdade de Ciências e

Publicado por: Tecnologia da Universidade de Coimbra, Departamento de Engenharia Mecânica

URL persistente:

URI:http://hdl.handle.net/10316.2/33349

DOI:

DOI:http://dx.doi.org/10.14195/978-972-8954-42-0_31

Accessed : $\quad$ 26-Apr-2023 09:57:05

A navegação consulta e descarregamento dos títulos inseridos nas Bibliotecas Digitais UC Digitalis, UC Pombalina e UC Impactum, pressupõem a aceitação plena e sem reservas dos Termos e Condições de Uso destas Bibliotecas Digitais, disponíveis em https://digitalis.uc.pt/pt-pt/termos.

Conforme exposto nos referidos Termos e Condições de Uso, o descarregamento de títulos de acesso restrito requer uma licença válida de autorização devendo o utilizador aceder ao(s) documento(s) a partir de um endereço de IP da instituição detentora da supramencionada licença.

Ao utilizador é apenas permitido o descarregamento para uso pessoal, pelo que o emprego do(s) título(s) descarregado(s) para outro fim, designadamente comercial, carece de autorização do respetivo autor ou editor da obra.

Na medida em que todas as obras da UC Digitalis se encontram protegidas pelo Código do Direito de Autor e Direitos Conexos e demais legislação aplicável, toda a cópia, parcial ou total, deste documento, nos casos em que é legalmente admitida, deverá conter ou fazer-se acompanhar por este aviso.

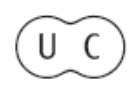




\title{
Reliability Analysis on Crucial Subsystems of a Wind Turbine through FTA Approach
}

\author{
S. Katsavounis ${ }^{1}$;N. Patsianis ${ }^{2}$; E.I. Konstantinidis ${ }^{3}$; P.N. Botsaris ${ }^{4}$ \\ 1.skatsav@pme.duth.gr; ${ }^{2}$ nikopats@pme.duth.gr; ${ }^{3}$ ekonstan@pme.duth.gr; ${ }^{4}$ panmpots@.pme.duth.gr \\ ${ }^{1,2,3,4}$ Democritus University of Thrace
}

School of Engineering, Department of Production and Management Engineering

12 Vas.Sofias Str., Xanthi, Greece, 67100

\begin{abstract}
The wind turbine reliability is a crucial factor for the successful operation of a wind power plant, affecting its availability and efficiency. Operation and maintenance costs affect the performance of the whole system and reinforce the necessity of redesign of specific sub-assemblies achieving lower energy production costs.

At the first stage, field data make up Weibull sets in order to form the appropriate distribution-curve of the failure rate in each corresponding top event, are presented. These sets are limited to sub-systems having not only adequate data of the corresponding top events, producing more realistic results, but also having great risk priority, according to FMEA approach. These Weibull sets are linked with the corresponding top event of each subsystem and used to quantify the failure rates.
\end{abstract}

The validation of previous studies made on wind turbine reliability FMEA analysis through the FTA method is investigated in this paper, as well as the results from previous studies made on reliability of wind turbines using the FMEA method. Though, the reliability and importance results as derived from a quantitative analysis, seem to be following the same trend like previous studies from different and various approaches. As a result, Electrical and Control systems as far as the Hydraulic System need to be re-designed with better performance and reliability since they are crucial for the operation of each WT separately as well as for the whole wind farm.

Keywords: Wind Turbines, Reliability, Fault-Tree Analysis, Weibull Analysis, Isograph Reliability

\section{INTRODUCTION}

During the last decades many changes in the electricity demand and generation have taken place in a global scale, promoting renewable energy resources instead of fossil fuels which are starting degrading. Markets have started turning to alternative and renewable energy resources accompanied with increasing demand and production of electricity. A renewable energy source that is used for the production of electrical power is wind power. Wind power has become one of the world's fastest growing renewable energy resource making it more attractive to even more companies and enterprises around the globe for use as a main source of power for their facilities. By all means, wind energy should not perceived as a complete alternative to common means of electricity production but it turns out to be a competitive and sustainable energy source. Fig. 1 shows the globally installed wind power capacity from 1997 to 2011. As a result, Wind Turbines (WT) have become very popular among other renewable energy resources.

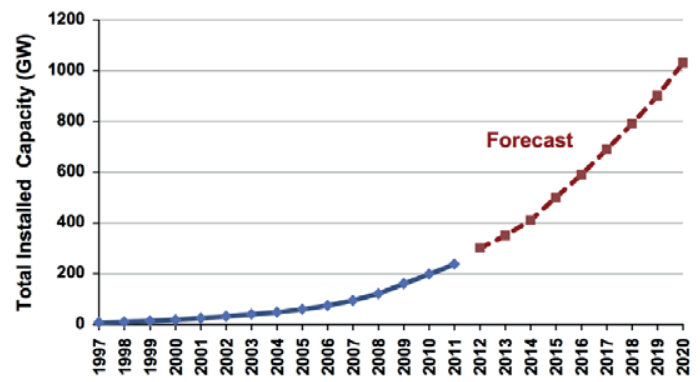

Fig.1. Wind energy: global capacity (blue) and forecast (red). [5]

Even though at a first glance, wind farms and the installation of wind turbines may seem simple, many factors must be considered such as the selection of the location of the wind farm, the layout of the wind turbines etc. All these operations and functions have proven quite costly. Operation and maintenance costs occupy a great share of the cost of a wind farm after its installation. Thus, the energy production of a wind farm depends on its reliability, meaning the reliability of each individual wind turbine as well as its subsystems. Fig.2 . [7] presents the main parts of a WT for the conversion of wind energy to electricity.

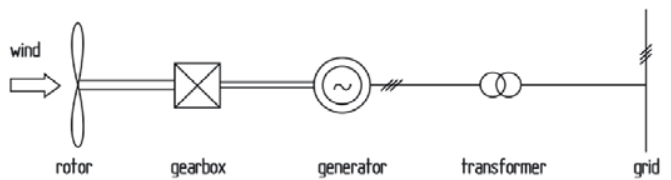

Fig.2.Mechanical-electrical functional chain in a wind turbine [7]

The reliability analysis methods used in the design stage of a WT are mostly qualitative while after some time of operation more evidence of components and sub-systems reliability are becoming available, providing engineers with adequate data to improve the design and the maintenance planning.

The fault tree analysis (FTA) has been widely used to measure and quantify the reliability of complex electromechanical systems, not only by identifying the most 
critical parts of the system, but also combining field data obtained from maintenance sheets and highlighting the most frequent top events. FTA is one of the most commonly used methods for reliability analysis along with Failure Modes and Effects Analysis (FMEA) [1] which supplement each other. FTA approach aims to quantify the reliability and availability of a complex system, in our case the Wind Turbine. The latter information provide useful data to engineers and end-users for maintenance planning reducing O\&M costs and finally leading to lower energy production costs. It is considered that wind turbines follow the bathtub curve illustrated in Fig. 3 which best describes the failure rates of a WT during its operational life considered between 20 to 25 years. At the first period, about 2 to 3 years of operation, it is clear that a high failure rate is presented which also is known as period of early failures. During the next period of useful life, there is a drop to the failure rates until the period of wearout comes after about 20 years of operation and the failure rates are starting increasing again, indicating the end of operational life of the WT.

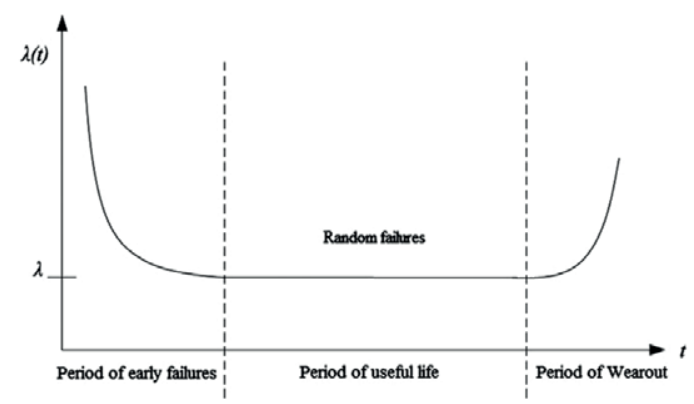

Fig. 3. Bathtub curve indicating the evolution of failure rate over the life cycle of a WT. [5]

The main objective of this paper is to apply FTA in a Wind Farm for reliability analysis of the most crucial sub-systems of its Wind Turbines.

\section{SYSTEM CHARACTERISTICS AND FAILURES}

The system analyzed in the current study is the WT. In Fig.4 a typical horizontal axis WT and its subsystems are illustrated. The main subsystems of a WT are:

\section{A. Rotor}

- Blades

- Hub

- Nose cone/spinner

- Pitch regulation systems

\section{B. Nacelle}

- Drive train

- Couplings

- Mechanical brake
- Generator

- Nacelle support frame

- Nacelle cover/enclosure

- Yaw systems

C. Tower

D. Foundation

E. Electrical and Control System

- Sensors

- Actuators

- Hardware/software

F. Hydraulic System

These subsystems together with failure data are further examined from the reliability point of view. The current Reliability Analysis and Data Failure Analysis regards a wind farm which consists of 10 horizontal axis wind turbines, located in a Greek island.

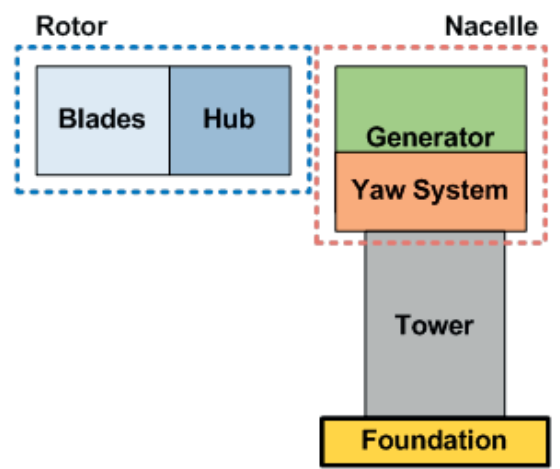

Fig. 4.Main Systems and Subsystems of a WT [ 4 ]

During the studied period, failures among all the subsystems took place with different failure rates and severities of failures. Some failures demanded the temporary shut down of the wind turbine for hours or even days. Such factors were not considered in the particular research, since our purpose is to propose a methodology for applying FTA using failure data of maintenance sheets which were provided by the personal record of the wind farm owner. During the development of the complete Fault Tree of the WT it was concluded that the main mechanisms that occur often and cause failures are the Corrosion, Mechanical overloads, Vibrations and Exposure to climatic extremes. According to a previous reliability analysis using the FMEA method [1] the above causes appear to be among the top 10 root causes. Table I shows the number of recorded failures that occurred during the 7.5-year studied period in all of the subsystems of the ten installed WTs of the wind farm. In Table II the failure rates from the subsystems were computed taking under 
consideration the examined period and the number of the WTs. From Tables I and II it is clear that the most crucial and important subsystems of the wind turbines of our studied wind farm are the Electrical and Control Systems and the Hydraulic System. The Gearbox is also considered to be a crucial wind turbine subsystem from Tables I and II, but it was not further analyzed with the proposed methodology since the wind farm owner did not provide detailed data for gearbox failures. So, the failure data from the gearbox failures were not able to be included in the proposed methodology.

TABLE I. SUMMARIZED NUMBER OF FAILURES IN THE WIND FARM

\begin{tabular}{|l|c|}
\hline \multicolumn{1}{|c|}{ Subsystem } & Number of failures \\
\hline Gearbox & 105 \\
\hline Brake system & 8 \\
\hline Hydraulic System & 97 \\
\hline Generator & 42 \\
\hline Yaw System & 44 \\
\hline Rotor & 19 \\
\hline Electrical \& Control Systems & 184 \\
\hline
\end{tabular}

TABLE II. SUBSYSTEMS FAILURE RATES

\begin{tabular}{|l|c|}
\hline \multicolumn{1}{|c|}{ Subsystem } & Failure rate, $\lambda(t)$ \\
\hline Gearbox & 1.4 \\
\hline Brake System & 0.1 \\
\hline Hydraulic System & 1.3 \\
\hline Generator & 0.6 \\
\hline Yaw System & 0.6 \\
\hline Rotor & 0.3 \\
\hline Electrical \& Control Systems & 2.5 \\
\hline
\end{tabular}

\section{RELIABILITY ANALYSIS}

Reliability, Availability and Maintainability and (RAM) are the most important factors that affect both the design and the life cycle of a machine, product or a system [9]. In order to perform reliability analysis using the Fault Tree Analysis approach of a system we need to have adequate data in order to construct its fault tree. At a prime stage the Tree will be more qualitative, determining the main events after analyzing the maintenance report sheets and deciding which gates should be used and defining main events interconnections. In the proposed study we used as failure data the times that each particular event (in hours) took place, having as a reference date the time that the farm owner started operating the farm. In our case this is the 1st of January 2005. In the next stage these failures were grouped into main events of the fault tree. After deciding which failure corresponds to each event, appropriate Weibull sets were developed using the Isograph Reliability Workbench [6] in order to estimate the Weibull set parameters which comply with each main event. The Weibull distribution is quite often used in reliability analysis applications rather than other distributions because it has the advantage to adapt its form depending on the samples values. So we can have as a result a variety of distribution shapes.

The 2-parameter Weibull distribution [6] probability density function as well as some reliability indicators in their mathematical form is described in eq. (1) to (4):

$$
f(t)=\frac{\beta t^{\beta-1}}{\eta} e^{-\left(\frac{t}{\eta}\right)^{\beta}}
$$

Where:

$\eta$ : characteristic life parameter

$\beta$ : shape parameter

Unreliability:

$$
F(t)=1-e^{-\left(\frac{t}{\eta}\right)^{\beta}}
$$

Failure rate:

$$
r(t)=\frac{\beta t^{\beta-1}}{\eta^{\beta}}
$$

Mean Time To Failure ( $M T T F)$ :

$$
M T T F=\eta \Gamma\left(\frac{1+\beta}{\beta}\right)
$$

Where:

$\Gamma=$ Gamma function

Availability:

$$
A=\frac{\text { uptime }}{\text { uptime }+ \text { downtime }}
$$

Isograph Reliability Workbench receives as inputs the failure times in hours for each main event and then estimates 
the parameters to form a unique distribution for each main event of our fault tree. Due to some inadequate data, to obtain more accurate parameter estimation and a whole perspective of the failures of the wind farm, the Weibull sets for each main event formed from failure data regarding the whole wind farm and not each wind turbine separately.

In the next stage, the Weibull sets with their parameters are linked with their corresponding Failure Model which indicates a specific main event in the Fault Tree. Due to the lack of information regarding the whole system and to make a simpler analysis approach, the Fault Trees of the Wind Turbine's Subsystems were constructed under the assumption that all gates are type 'OR'.

The fault tree of a Wind Turbine with its main subsystem as illustrated in Fig. 5 includes the following branches:

\section{A. Foundation}

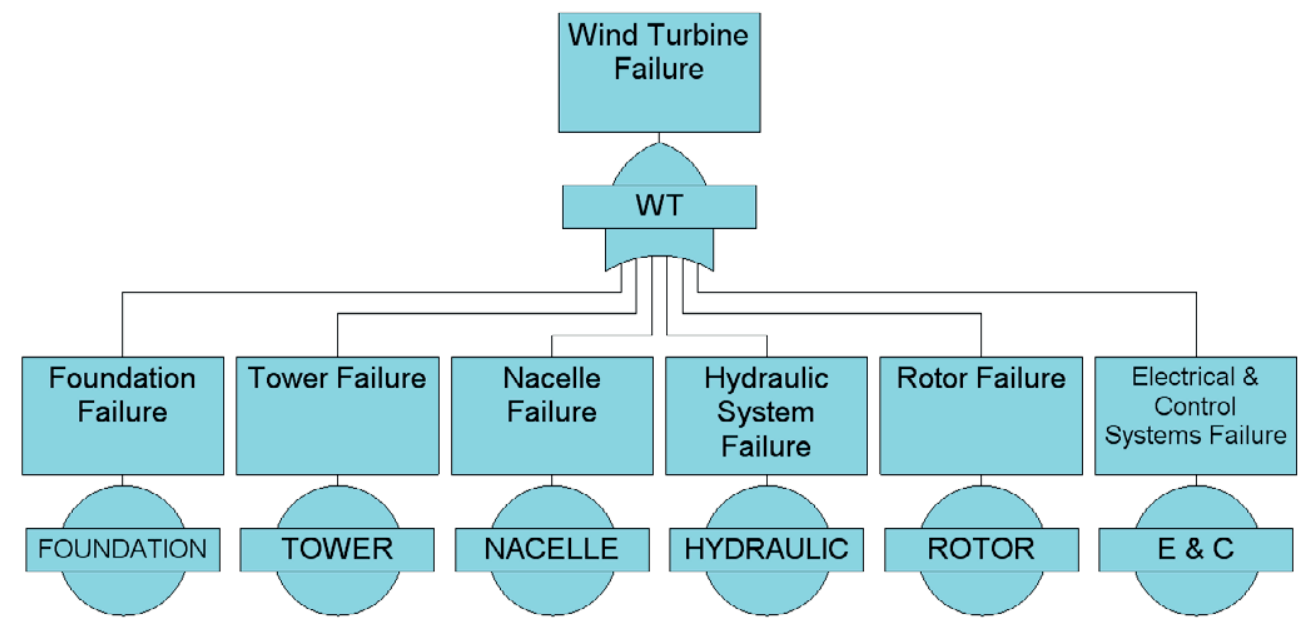

Fig. 5.Fault tree of a WT with its basic subsystems

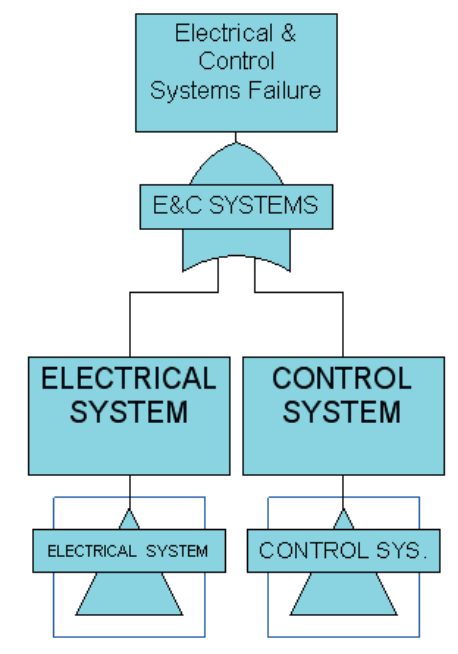

Fig. 6.Electrical \& Control Systems Fault Tree

B. Tower

C. Nacelle

D. Hydraulic System

E. Rotor(Blades \& Hub)

\section{F. Electrical \& Control Systems}

Fig. 6-9 illustrates the Fault Trees of the Electrical and Control System combined, the Electrical System, the Control System and the Hydraulic System, respectively.

Tables from III to VI present the analysis results for each discussed sub-system. Due to the lack of sufficient data, only certain reliability indicators are presented in the current study. In the reliability analysis is included the Availability, the Frequency of failures, the Reliability and the Mean Time To Failure among all components of the subsystems in hourly scale. 


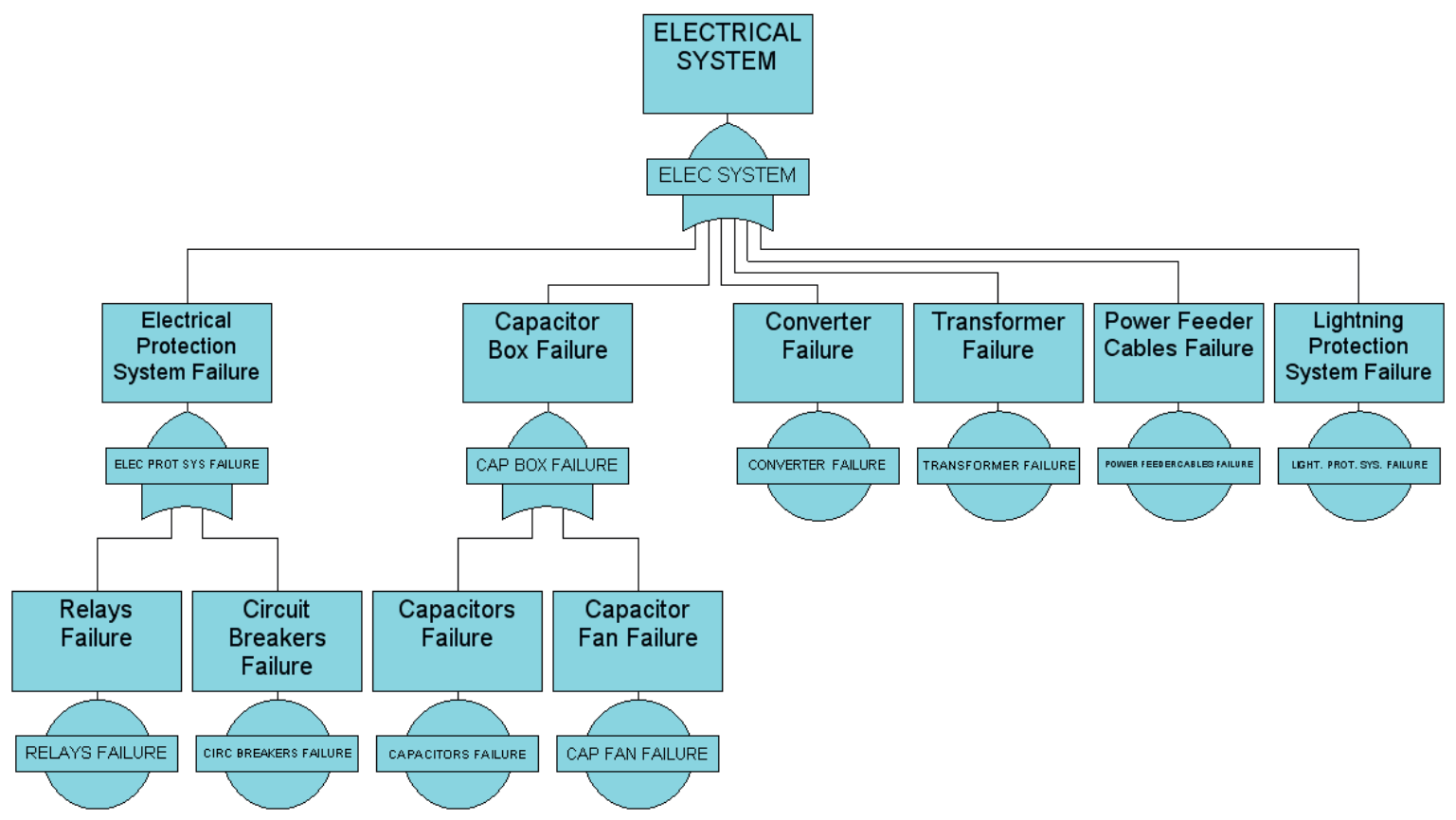

Fig. 7. Electrical System Fault Tree

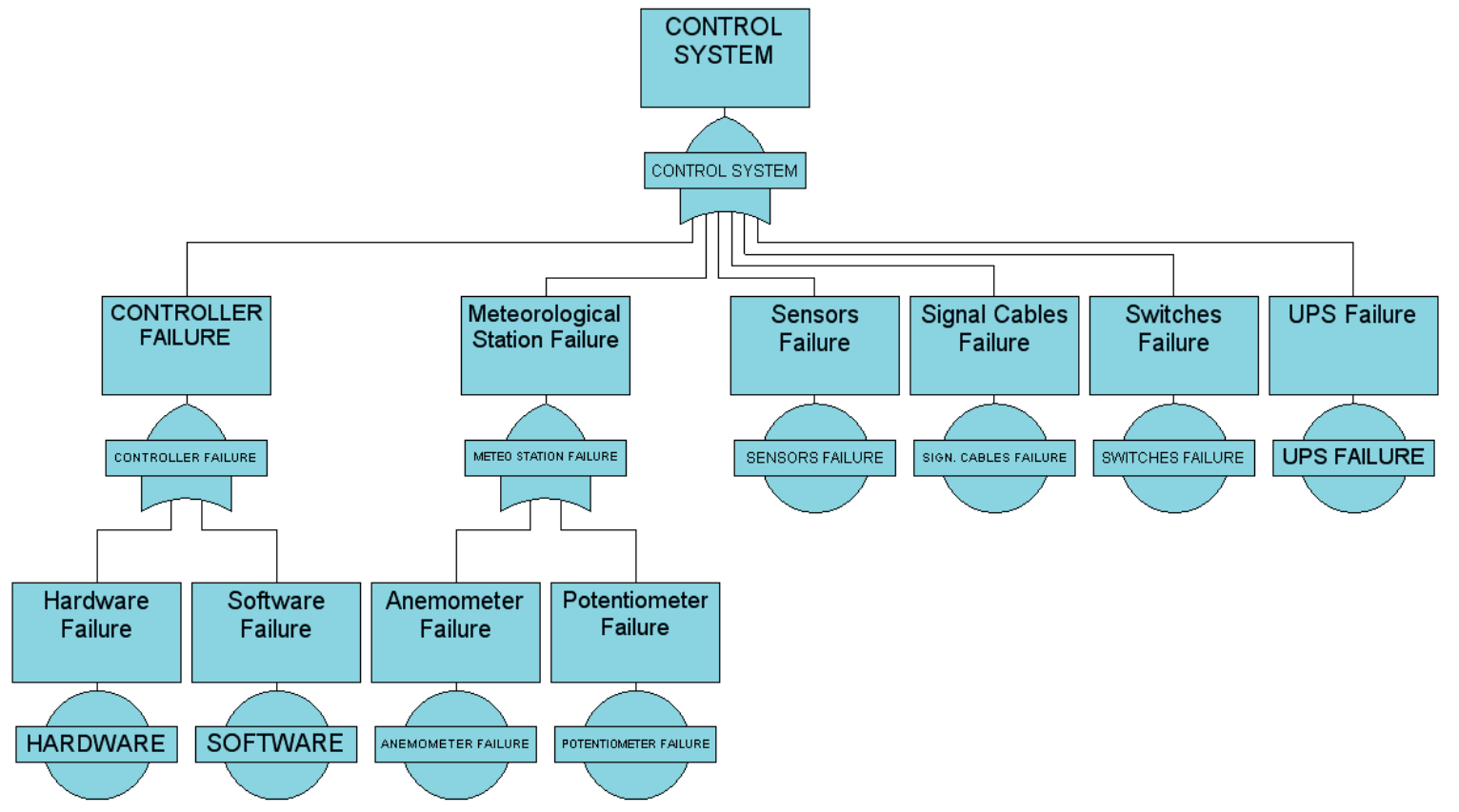

Fig. 8.Control System Fault Tree 


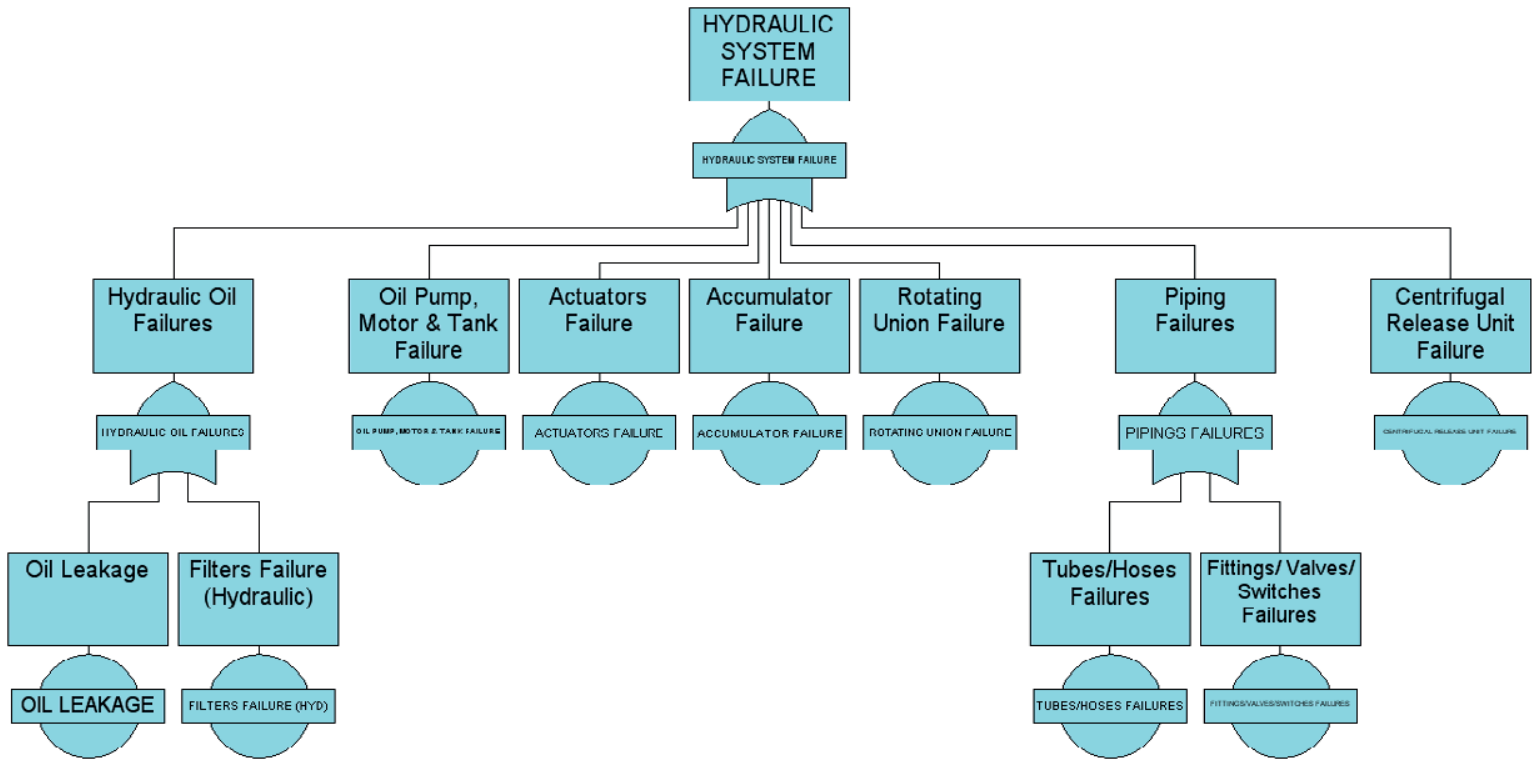

Fig. 9.Hydraulic System Fault Tree

TABLE III. ELECTRICAL AND CONTROL SYSTEM RELIABILITY INDICATORS

\begin{tabular}{|l|c|}
\hline \multicolumn{2}{|c|}{ Electrical \& Control Systems Failure } \\
\hline Availability & 0.9811 \\
\hline Frequency & 0.0091 \\
\hline Reliability & 0.9907 \\
\hline Mean Time To Failure (MTTF) & 1513 \\
\hline
\end{tabular}

TABLE IV. ELECTRICAL SYSTEM RELIABILITY INDICATORS

\begin{tabular}{|l|c|}
\hline \multicolumn{2}{|c|}{ Electrical System Failure } \\
\hline Availability & 0.9886 \\
\hline Frequency & 0.0052 \\
\hline Reliability & 0.9948 \\
\hline Mean Time To Failure (MTTF) & 3762 \\
\hline
\end{tabular}

TABLE V. CONTROL SYSTEM RELIABILITY INDICATORS

\begin{tabular}{|l|c|}
\hline \multicolumn{2}{|c|}{ Control System Failure } \\
\hline Availability & 0.9925 \\
\hline Frequency & 0.0040 \\
\hline Reliability & 0.9960 \\
\hline Mean Time To Failure (MTTF) & 3600 \\
\hline
\end{tabular}

TABLE VI. HYDRAULIC SYSTEM RELIABILITY INDICATORS

\begin{tabular}{|l|c|}
\hline \multicolumn{2}{|c|}{ Hydraulic System Failure } \\
\hline Availability & 0.9957 \\
\hline Frequency & 0.0023 \\
\hline Reliability & 0.9977 \\
\hline Mean Time To Failure (MTTF) & 6769 \\
\hline
\end{tabular}

Along with the reliability analysis it is useful to present the importance analysis of each component of each sub-system. Importance measures establish the significance for all the events in the Fault Tree in terms of their contributions to the top event probability. Both intermediate events (gate events) as well as basic events can be prioritized according to their importance [8]. The importance analysis is based on three basic Fault Tree Importance measures which include the Fussell-Vesely (FV) Importance, the Risk Achievement Worth (RAW) and the Risk Reduction Worth (RRW) [8]. The Fussell-Vesely importance indicates the relative contribution to the system failure probability from a component failure. Increasing the availability of components with high important values will have the most significant effect on system availability, consequence frequency or risk. The Risk Achievement Worth indicator represents the worth of the component associated with the Fault Tree event in achieving the present level of risk and indicates the importance of maintaining the present level of reliability for the component. The Risk Reduction Worth importance represents the maximum reduction in risk for an improvement to the component associated with the Fault Tree event.

Table VII summarizes the Electrical and Control Systems importance into one system, considering the Electrical System as one component and the Control System as the other. Table VII confirms that in the Electrical and Control System, the Electrical system has a more important role and is more critical than Control System. According to Table VIII, the more important components into the Electrical System include Power feeder cables and the Lightning protection system. According to Table IX, the most important component in the Control System, indicating a very high rate, appears to be the Controller. Table $\mathrm{X}$ regards the Hydraulic System and 
indicates Pipings as the most important component of the system.

TABLE VII. .ELECTRICAL \& CONTROL SySTEMS IMPORTANCE

\begin{tabular}{|l|c|c|c|}
\hline Components & $\begin{array}{c}\text { Fussell- } \\
\text { Vesely }\end{array}$ & $\begin{array}{c}\text { Risk } \\
\text { Achievement } \\
\text { Worth }\end{array}$ & $\begin{array}{c}\text { Risk } \\
\text { Reduction } \\
\text { Worth }\end{array}$ \\
\hline $\begin{array}{l}\text { Electrical } \\
\text { System }\end{array}$ & 0.6024 & 53.04 & 2.515 \\
\hline $\begin{array}{l}\text { Control } \\
\text { System }\end{array}$ & 0.3976 & 53.25 & 1.66 \\
\hline
\end{tabular}

TABLE VIII. ELECTRICAL SYSTEM IMPORTANCE

\begin{tabular}{|l|c|c|c|}
\hline Components & $\begin{array}{c}\text { Fussell- } \\
\text { Vesely }\end{array}$ & $\begin{array}{c}\text { Risk } \\
\text { Achievement } \\
\text { Worth }\end{array}$ & $\begin{array}{c}\text { Risk } \\
\text { Reduction } \\
\text { Worth }\end{array}$ \\
\hline $\begin{array}{l}\text { Power } \\
\text { feeder } \\
\text { cables }\end{array}$ & 0.8356 & 87.41 & 6.081 \\
\hline $\begin{array}{l}\text { Lightning } \\
\text { protection } \\
\text { system }\end{array}$ & 0.1580 & 88.08 & 1.188 \\
\hline $\begin{array}{l}\text { Electrical } \\
\text { protection } \\
\text { system }\end{array}$ & 0.0039 & 88.24 & 1.004 \\
\hline $\begin{array}{l}\text { Capacitor } \\
\text { box }\end{array}$ & 0.0013 & 88.24 & 1.001 \\
\hline Converter & 0.0011 & 88.24 & 1.001 \\
\hline Transformer & 0.0001 & 88.24 & 1 \\
\hline
\end{tabular}

TABLE IX. CONTROL SYSTEM IMPORTANCE

\begin{tabular}{|l|c|c|c|}
\hline Components & $\begin{array}{c}\text { Fussell- } \\
\text { Vesely }\end{array}$ & $\begin{array}{c}\text { Risk } \\
\text { Achievement } \\
\text { Worth }\end{array}$ & $\begin{array}{c}\text { Risk } \\
\text { Reduction } \\
\text { Worth }\end{array}$ \\
\hline Controller & 0.9329 & 132.4 & 14.91 \\
\hline $\begin{array}{l}\text { Meteorological } \\
\text { station }\end{array}$ & 0.0600 & 133.3 & 1.064 \\
\hline Switches & 0.0053 & 133.3 & 1.005 \\
\hline UPS & 0.0017 & 133.3 & 1.002 \\
\hline Sensors & 0.0007 & 133.3 & 1 \\
\hline Signal cables & 0.0005 & 133.3 & 1 \\
\hline
\end{tabular}

TABLE X. HydRAULIC SYSTEM IMPORTANCE

\begin{tabular}{|l|c|c|c|}
\hline Components & $\begin{array}{c}\text { Fussell- } \\
\text { Vesely }\end{array}$ & $\begin{array}{c}\text { Risk } \\
\text { Achievement } \\
\text { Worth }\end{array}$ & $\begin{array}{c}\text { Risk } \\
\text { Reduction } \\
\text { Worth }\end{array}$ \\
\hline Pipings & 0.8458 & 232 & 6.485 \\
\hline $\begin{array}{l}\text { Oil } \\
\text { pump,motor } \\
\& \text { tank }\end{array}$ & 0.1334 & 232.7 & 1.154 \\
\hline $\begin{array}{l}\text { Hydraulic } \\
\text { oil }\end{array}$ & 0.0208 & 232.8 & 1.021 \\
\hline $\begin{array}{l}\text { Rotating } \\
\text { union }\end{array}$ & 0.0001 & 232.9 & 1 \\
\hline Accumulator & 0.0001 & 232.9 & 1 \\
\hline $\begin{array}{l}\text { Centrifugal } \\
\text { release unit }\end{array}$ & 0 & 232.9 & 1 \\
\hline Actuators & 0 & 232.9 & 1 \\
\hline
\end{tabular}

\section{CONCLUSIONS AND FURTHER RESEARCH}

Performing a reliability analysis through FTA approach a sufficient amount of data is needed, along with information from maintenance sheets and diagrams indicating connections between all components of the systems. The reliability and importance results, as derived from a quantitative analysis, seem to be following the same trend like previous studies from different and various approaches [5]. Electrical and Control systems as far as the Hydraulic System need to be re-designed to demonstrate better performance and reliability, being crucial to the operation of the WTs and the total efficiency of the wind farm. Many failures appear to be of minor consideration, but when it comes to measure the reliability of the systems involved them, their importance seems to affect it. When more failure data are available from other subsystems, a relative research could illustrate a more holistic view of the reliability of a WT. The full fault tree of the studied WT is available from the authors upon request.

As an expansion from the current study, a sensitivity analysis on the parameter estimation of the Weibull sets using Monte Carlo simulations would indicate the variation of each system's reliability. Drawing directions for better maintenance planning and promote new and more reliable WT designs achieve high rates of reliability and availability, reduce failure rates of subsystems and components and improve the reliability of a whole wind farm.

\section{ACKNOWLEDGEMENT}

We would like to acknowledge the contribution and support of Isograph for providing us with an academic license of their products, Availability and Reliability Workbenches ver.11.1.

\section{REFERENCES}

[1] H. Arabian-Hoseynabadi, H. Oraee and P.J. Tavner "Failure modes and effects analysis (FMEA) for wind turbines", Electrical Power and Energy Systems, vol. 32,pp. 817-824, Elsevier, 2010.

[2] H.Guo, S.Watson, P.Tavner and J. Xiang "Reliability analysis for wind 
turbines with incomplete failure data collected from after the date of initial installation”, Reliability Engineering and System Safety, vol. 94, pp.1057-1063, Elsevier, 2009.

[3] F. Spinato, P.J. Tavner, G.J.W. van Bussel and E. Koutoulakos "Reliability of wind turbine subassemblies", IET, Renewable Power Generation, Vol. 3, Iss. 4, pp. 1-15, 2009.

[4] P. N. Botsaris, E.I. Konstantinidis and D. Pitsa "Systemic assessment and analysis of factors affect the reliability of a wind turbine", Journal of Applied Engineering Science, no. 10, vol.2, pp. 85-92, 2012.

[5] J.M.P. Pérez, F.P.G. Márquez, A. Tobias and M.Papaelias "Wind turbine reliability analysis", Renewable and Sustainable Energy Reviews, vol. 23, pp. 463-472, Elsevier, 2013.
[6] Isograph Reliability Workbench Version 11.1 User Guide, Isograph, 2011.

[7] E. Hau "Wind Turbines Fundamentals, Technologies, Application, Economics", $2^{\text {nd }}$ edition, Springer, 2006.

[8] Fault Tree Handbook with Aerospace Applications, NASA Headquarters, August 2002.

[9] B.S. Dhillon, Engineering Maintainability, Gulf Publising Company, 2006 